\title{
Enzymatic activity of three sugarcane varieties under salt stress
}

\author{
Mercia F. Carvalho' ${ }^{1}$, Marcus M. Correa ${ }^{1}$, Gian C. Carvalho², \\ Fernando C. Rolim Neto' ${ }^{1}$ Gessica P. A. Marinho ${ }^{3}$ \& Sunamita B. de Andrade ${ }^{3}$ \\ ${ }^{1}$ Universidade Federal Rural de Pernambuco/Departamento de Tecnologia Rural/Programa de Pós-graduação em Engenharia Ambiental. Recife, PE. E-mail: \\ mercia.fonseca@hotmail.com (Corresponding author); metri@dtr.ufrpe.br; fernandocartaxo@yahoo.com.br \\ ${ }^{2}$ Instituto Federal de Educação, Ciência e Tecnologia do Piauí/Departamento de Tecnologia Agrícola. Valença, PI. E-mail: giancarvalho@gmail.com \\ ${ }^{3}$ Universidade Federal Rural de Pernambuco/Unidade Acadêmica de Engenharia Agrícola Ambiental. Recife, PE. E-mail: gessica.marinho1993@gmail.com; \\ mariosantos90@hotmail.com.br
}

Key words:

salinity

antioxidant enzymes

resistance

\begin{abstract}
A B S T R A C T
Sugarcane is a species of great economic importance to Brazil. The study of enzymatic activity has helped to identify varieties of sugarcane tolerant to salt stress, for planting in Brazilian semiarid regions, where there is the occurrence of saline soils. The objective of this study was to evaluate the enzymatic activity of three varieties of sugarcane subjected to stress caused by salinity. The experiment was conducted in a greenhouse at the Federal Rural University of Pernambuco, in a completely randomized design with four replicates. The leaf blade samples were collected for analysis of soluble proteins and determination of the activity of catalase and ascorbate peroxidase. The protein content was higher for RB962962 and lower for the varieties RB92579 and RB867515. However, in RB867515, there was an increase in the activity of ascorbate peroxidase and catalase, while the varieties RB92579 and RB962962 showed a reduction in the activity of these enzymes. These results indicate that the variety RB867515 has a more efficient mechanism in plant protection against the action of reactive oxygen species.
\end{abstract}

Palavras-chave:

salinidade enzimas antioxidantes resistência

\section{Atividade enzimática de três variedades de cana-de-açúcar sob estresse salino}

\begin{abstract}
R E S U M O
A cana-de-açúcar é uma espécie de grande importância econômica para o Brasil. O estudo da atividade enzimática tem ajudado a identificar variedades de cana-de-açúcar tolerantes ao estresse salino para plantio nas regiões semiáridas brasileiras nas quais ocorre incidência de solos salinizados. Objetivou-se, neste estudo, avaliar a atividade enzimática de três variedades de cana-de-açúcar submetidas ao estresse causado pela salinidade. O experimento foi conduzido em casa de vegetação na Universidade Federal Rural de Pernambuco. Foi feito um delineamento inteiramente casualizado, com quatro repetições. Foram coletadas amostras do limbo foliar para análise das proteínas solúveis e determinação da atividade das enzimas catálase e ascorbato peroxidase. O teor de proteínas foi maior para a variedade RB962962 and menor para as variedades RB92579 e RB867515; entretanto se percebeu, na variedade RB867515, aumento da atividade da ascorbato peroxidase e da catálase enquanto que nas variedades RB92579 e RB962962 ocorreu uma redução da atividade dessas enzimas cujos resultados indicam que a variedade RB867515 apresenta um mecanismo mais eficiente na proteção da planta contra a ação de espécies reativas de oxigênio.
\end{abstract}




\section{INTRODUCTION}

Sugarcane is the main raw material for the production of sugar and alcohol (Marin \& Nassif, 2013). It has environmental importance for producing ethanol and showing high atmospheric $\mathrm{CO}_{2}$ fixation rate, for a prolonged period of time, naturally contributing to the improvement of the environment and reducing the greenhouse effect caused by the burning of fossil fuels (Gallardo \& Bond, 2010; Sundfeld \& Machado, 2011).

In northeast of Brazil, where sugarcane production is very significant (CONAB, 2014), the area of soils degraded by salinity and sodicity has increased due to the expansion of irrigated areas in marginal lands, inadequate management of water and soil, deficient drainage and the use of saline waters in irrigation.

It is known that the effect of salinity on plants causes loss of quality and yield, affecting plant growth through osmotic stress and toxicity caused by the excessive accumulation of salts in the leaves (Siripornadulsil et al., 2012).

As a resistance to the stress, plants create antioxidant defense mechanisms capable of neutralizing the cytotoxicity of reactive oxygen species (ROS) (Agarwal \& Pandey, 2004). Among the various enzymes that act in this system, catalases (CAT), ascorbate peroxidase (APX) and superoxide dismutases (SODs) stand out (Miller et al., 2010). Through the activity of the enzymes, plants protect their cells from the toxic effects of ROS (Foyer \& Shigeoka, 2011; Barbosa et al., 2014).

This study aimed to evaluate the responses of the antioxidant system, sugarcane varieties and the defense mechanisms of these plants to the salt stress, and identify varieties more tolerant to this stress.

\section{Material AND Methods}

The experiment was carried out in a greenhouse at the Federal Rural University of Pernambuco (UFRPE), in Recife$\mathrm{PE}$, Brazil, using the billets of three sugarcane varieties tolerant to salinity: RB92579, RB962962 and RB867515; provided by the Sugarcane Experimental Station of Carpina (EECAC).

The completely randomized experimental design was used in a $3 \times 5$ factorial scheme, which corresponded to three sugarcane varieties whose seedlings were irrigated with five levels of salinity $(0,50,100,150$ and $200 \mathrm{mM}$ of $\mathrm{NaCl})$; each treatment comprised four replicates.

Plants were acclimated for 20 days and potassium and nitrogen fertilizations were performed according to crop needs, based on the Manual of Fertilization for the state of Pernambuco (IPA, 2008). In order to determine the replenishments with saline solutions, the pot capacity weight was determined and, after a fixed irrigation interval of four days, the pots were weighed again. The difference between the readings $(\mathrm{kg}$ ) determined the volume of solution $(\mathrm{L})$ to be applied in each irrigation event.

For the enzymatic analyses, the leaves were collected after thirty days, when samples of the leaf blade of the third fully expanded leaf were collected, counting from the apex to the base of the plant, immediately stored and aluminum paper envelopes and immersed in liquid nitrogen $\left(\mathrm{LN}_{2}\right)$ for a fast freezing of the material. Then, all the material was stored in a freezer at $-20^{\circ} \mathrm{C}$ until the analyses.

One extraction of proteins was performed using samples that were frozen, macerated and homogenized with buffer of $100 \mathrm{mM}$ potassium phosphate ( $\mathrm{pH} 7.5), 1 \mathrm{mM}$ of EDTA (ethylenediaminetetraacetic acid), $3 \mathrm{mM}$ DL-dithiothreitol and 20\% PVPP (polyvinyl polypyrrolidone) at temperature of

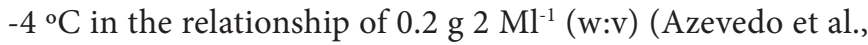
1998). The homogenized material was centrifuged at 10,000 $\mathrm{rpm}$ for $15 \mathrm{~min}$. The supernatant solution was stored at -20 ${ }^{\circ} \mathrm{C}$ and used as source for the determination of total proteins (TP) and activity of the enzymes catalase (CAT) and ascorbate peroxidase (APX). Enzymatic activities were expressed in enzymatic unit. One unit of the enzyme is defined as the amount of enzyme that causes an increase of 0.001 absorbance unit per minute, expressed as $\mathrm{U} \mathrm{min}^{-1} \mathrm{mg}^{-1}$ of soluble protein.

The concentration of soluble proteins was determined using BSA (bovine serum albumin) as the standard. The reaction was performed with the addition of $20 \mu \mathrm{L}$ of the sample (previously diluted) at $1 \mathrm{~mL}$ of the reagent Bradford and incubated at ambient temperature, for $5 \mathrm{~min}$. Then, the reading was performed in spectrophotometer at $595 \mathrm{~nm}$.

CAT activity was determined through the method described by Azevedo et al. (1998) with modifications, in solution containing $1 \mathrm{~mL}$ of the buffer $100 \mathrm{mM}$ potassium phosphate ( $\mathrm{pH} 7.5)$ and $25 \mu \mathrm{L}$ of hydrogen peroxide $\left(\mathrm{H}_{2} \mathrm{O}_{2}\right)$ at $1 \mathrm{mM}$. The reaction was initiated by the addition of $25 \mu \mathrm{L}$ of the protein extract and the activity was determined through the decomposition of $\mathrm{H}_{2} \mathrm{O}_{2}$ for $60 \mathrm{~s}$, based on the alterations at $240 \mathrm{~nm}$ at the temperature of $25^{\circ} \mathrm{C}$, in spectrophotometer.

APX activity was determined through a reaction composed of $650 \mu \mathrm{L}$ of the buffer $80 \mathrm{mM}$ potassium phosphate ( $\mathrm{pH} 7.5$ ), $100 \mu \mathrm{L}$ of $5 \mathrm{mM}$ ascorbate, $100 \mu \mathrm{L}$ of $1 \mathrm{M}$ EDTA, $100 \mu \mathrm{L}$ of 1 $\mathrm{mM} \mathrm{H}_{2} \mathrm{O}_{2}$ and $50 \mu \mathrm{L}$ of the protein extract. APX activity was determined through the monitoring of ascorbate oxidation rate at $290 \mathrm{~nm}$, at $30^{\circ} \mathrm{C}$, for $60 \mathrm{~s}$, in spectrophotometer.

The data were subjected to analysis of variance (ANOVA), using the program SISVAR ${ }^{\oplus}$. For all data, the quantitative factor relative to the salinity levels was statistically analyzed through regression, aiming the fit of equations in order to correlate the salinity levels with the studied variables. The means of the treatments were compared by Tukey test at 0.05 probability level.

\section{Results AND Discussion}

The results of the evaluations of soluble proteins (SP) and enzymatic activity (catalase (CAT), ascorbate peroxidase (APX)) are respectively presented in Figures 1 to 3 and Table 1.

Considering the evaluation of soluble proteins, the variety RB962962 statistically differed from RB92579 and RB867515 (Table 1 and Figure 1A). The increase in salinity may cause different responses among the protein contents. These differences may be related to intrinsic characteristics of the genotypes, as reported by Siripornadulsil et al. (2012). Figure $1 \mathrm{~B}$ and Table 1 show a mean reduction of $58 \%$ in the protein content for the treatment of highest saline concentration 
Table 1. Evaluation of soluble proteins and the enzymatic activity of catalase and ascorbate peroxidase in sugarcane varieties subjected to different salinity levels

\begin{tabular}{|c|c|c|c|c|c|c|c|}
\hline \multirow{2}{*}{ Variety } & \multicolumn{5}{|c|}{ NaCl levels (mM) } & \multirow{2}{*}{ Regression equation } & \multirow{2}{*}{$\mathbf{R}^{2}$} \\
\hline & 0 & 50 & 100 & 150 & 200 & & \\
\hline \multicolumn{8}{|c|}{ Soluble proteins ( $\mathrm{mg} \mathrm{g}^{-1}$ of DM) } \\
\hline RB92579 & $6.153 \mathrm{a}$ & $4.133 \mathrm{~b}$ & $3.263 \mathrm{bc}$ & $3.207 \mathrm{bc}$ & $2.715 \mathrm{C}$ & $y=0.0001 x^{2}-0.0377 x+6.0075$ & 0.96 \\
\hline RB962962 & $8.484 \mathrm{a}$ & $7.096 \mathrm{~b}$ & $5.014 \mathrm{c}$ & $5.474 \mathrm{c}$ & $3.559 \mathrm{~d}$ & $y=4 E-05 x^{2}-0.0314 x+8.4324$ & 0.91 \\
\hline RB867515 & $5.117 \mathrm{a}$ & $5.026 \mathrm{a}$ & $1.841 \mathrm{C}$ & $3.584 \mathrm{~b}$ & $1.897 \mathrm{c}$ & $y=5 E-05 x^{2}-0.0257 x+5.3174$ & 0.62 \\
\hline \multicolumn{8}{|c|}{ Catalase $\left(\mu \mathrm{mol} \mathrm{H}_{2} \mathrm{O}_{2} \mathrm{mg}^{-1}\right.$ of protein $\left.\mathrm{min}^{-1}\right)$} \\
\hline RB92579 & $581.9 \mathrm{a}$ & $651.84 \mathrm{a}$ & $725.56 \mathrm{a}$ & $714.58 \mathrm{a}$ & $624.12 \mathrm{a}$ & $y=-0.0116 x^{2}+2.6115 x+572.24$ & 0.94 \\
\hline RB962962 & 292.89 b & $301.73 \mathrm{~b}$ & $454.72 a b$ & $402.63 a b$ & $610.23 \mathrm{a}$ & $y=0.0055 x^{2}+0.3715 x+292.82$ & 0.84 \\
\hline RB867515 & $429.68 \mathrm{c}$ & $495.47 \mathrm{C}$ & $1608.64 \mathrm{a}$ & $1085.08 \mathrm{~b}$ & $1122.82 \mathrm{~b}$ & $y=-0.0484 x^{2}+13.625 x+311.33$ & 0.62 \\
\hline \multicolumn{8}{|c|}{ Ascorbate peroxidase $\left(\mu \mathrm{mol} \mathrm{H}_{2} \mathrm{O}_{2} \mathrm{mg}^{-1}\right.$ of protein $\left.\mathrm{min}^{-1}\right)$} \\
\hline RB92579 & $8514.98 \mathrm{~b}$ & $15331.41 \mathrm{a}$ & $16297.99 \mathrm{a}$ & $17895.21 \mathrm{a}$ & $5760.30 \mathrm{~b}$ & $y=-1.0649 x^{2}+207.09 x+8024.5$ & 0.88 \\
\hline RB962962 & $6222.07 \mathrm{c}$ & $7252.12 \mathrm{bc}$ & $10523.42 \mathrm{~b}$ & $11003.76 \mathrm{~b}$ & $15504.23 \mathrm{a}$ & $y=0.1186 x^{2}+20.918 x+6230.8$ & 0.95 \\
\hline RB867515 & $9930.84 \mathrm{C}$ & $14867.51 b$ & $35121.53 \mathrm{a}$ & 19029.42 b & $31582.21 \mathrm{a}$ & $y=-0.6033 x^{2}+215.58 x+9597.1$ & 0.54 \\
\hline
\end{tabular}

Same lowercase letters between varieties do not differ by Tukey test $(p<0.05)$
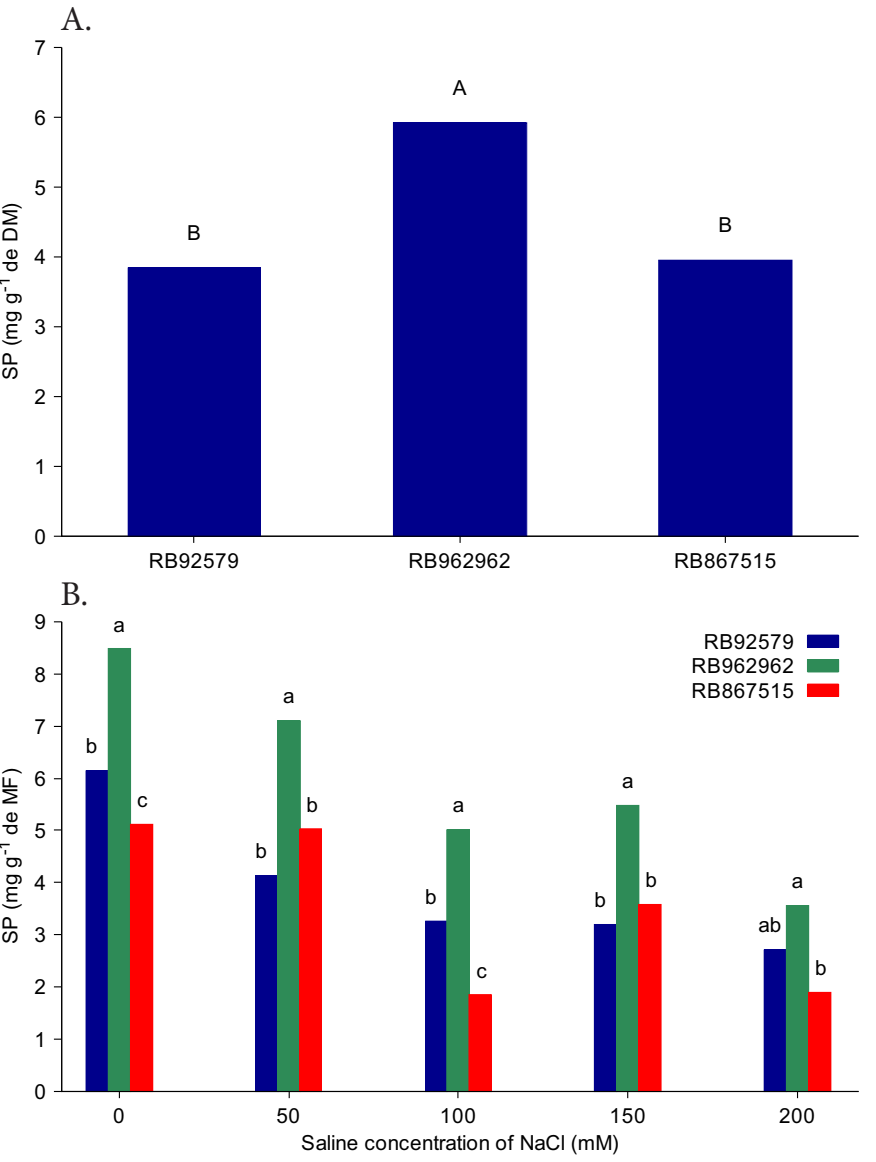

Means of a variety followed by same letters do not differ by Tukey test at 0.05 probability level Figure 1. Evaluation of soluble proteins (SP) (mg g-1 of DM) of sugarcane leaves. (A) Comparison between SP values obtained for the varieties subjected to different levels of salt stress; (B) Comparison between SP values obtained for the varieties at each studied saline level

(200 mM), compared with the control. Arias et al. (1996), for sugarcane, observed a reduction of $54.1 \%$ in the accumulation of soluble proteins, for the highest level of water deficit. Silva (2010), in studies with six sugarcane genotypes subjected to water stress, observed a mean reduction of $16 \%$ in soluble proteins for the severe stress, in relation to the control.

Parida \& Das (2005) reported that, under stress conditions, the protein content in the plants may decrease due to the increase of proteolysis. In addition, according to Gill \& Tuteja
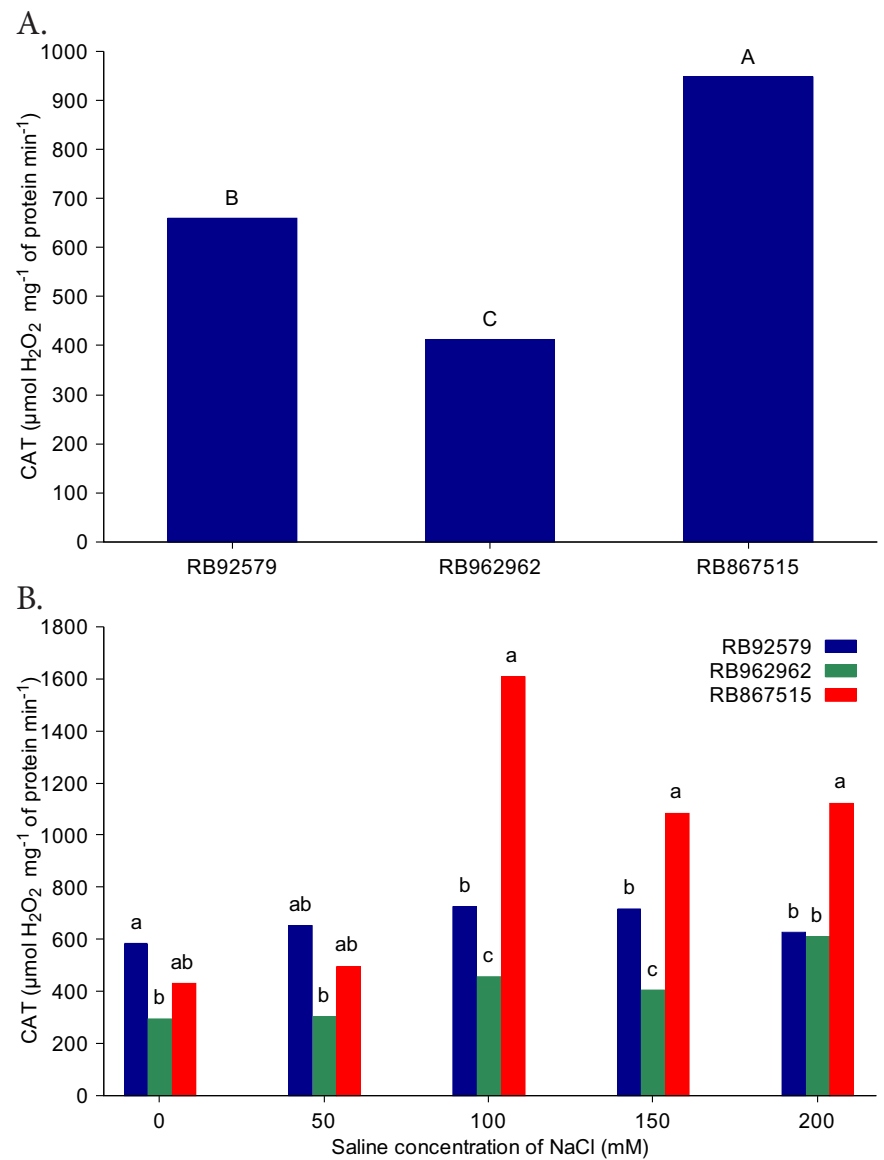

Means of a variety followed by same letters do not differ by Tukey test at 0.05 probability level Figure 2. Evaluation of the catalase (CAT) activity ( $\mu \mathrm{mol}$ $\mathrm{H}_{2} \mathrm{O}_{2} \mathrm{mg}^{-1}$ of protein $\mathrm{min}^{-1}$ ) of sugarcane leaves. (A) Comparison between CAT values obtained for the varieties subjected to different levels of salt stress; (B) Comparison between CAT values obtained for the varieties at each studied saline level

(2010), ROS accumulation may severely affect cell functionality and integrity with alterations in redox homeostasis, damages to macromolecules and denaturation of proteins. Castrillo et al. (2001) highlighted that, at a cellular level, proteins can be damaged by the lack of hydration, which promotes an increase of reactive oxygen species.

In the evaluation of catalase and ascorbate peroxidase enzymatic activities (Table 1 and Figures 2 and 3 (A and B)), 
A.

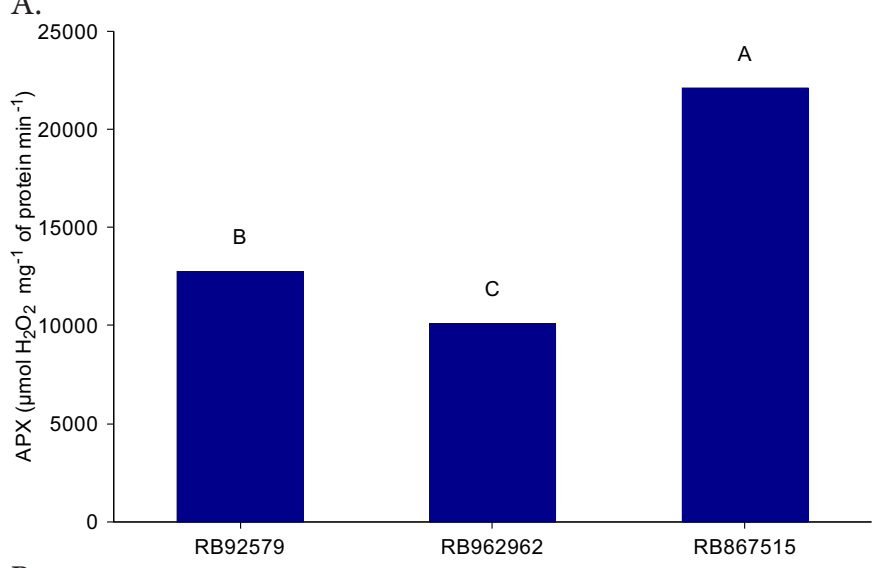

B.

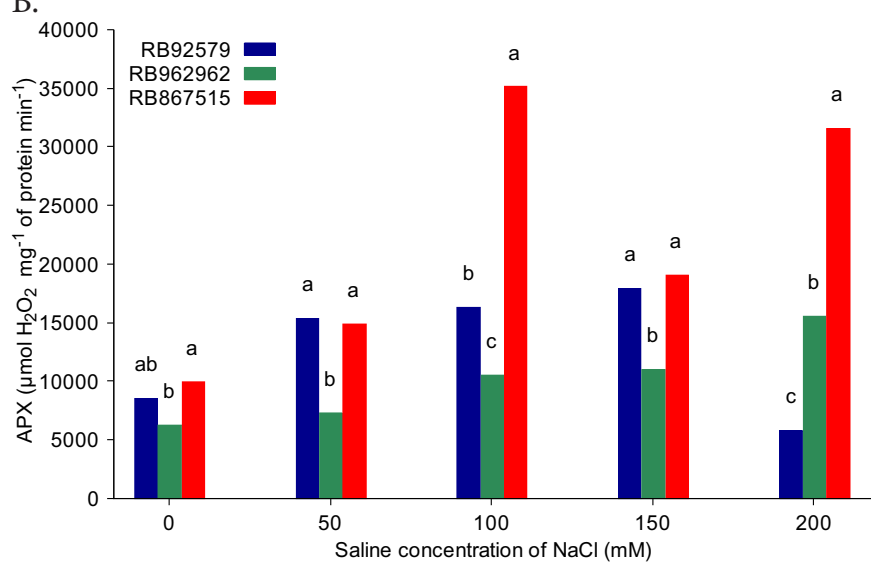

Means of a variety followed by same letters do not differ by Tukey test at 0.05 probability leve Figure 3. Evaluation of the ascorbate peroxidase (APX) activity $\left(\mu \mathrm{mol} \mathrm{H}_{2} \mathrm{O}_{2} \mathrm{mg}^{-1}\right.$ of protein $\mathrm{min}^{-1}$ ) of sugarcane leaves. (A) Comparison between APX values obtained for the varieties subjected to different levels of salt stress; (B) Comparison between APX values obtained for the varieties at each saline level

the variety RB867515 promoted higher values compared with RB92579 and RB962962, indicating its greater capacity of adaptation to salt stress. The variety RB962962 presented the lowest value and, therefore, lower capacity of adaptation to stress. These data corroborate those observed by Willadino et al. (2011), who evaluated the salt stress on the variety RB861515 and observed a more efficient mechanism in the protection of the plant against the action of reactive oxygen species, particularly $\mathrm{H}_{2} \mathrm{O}_{2}$, due to the increase in the activities of the enzymes CAT and APX. The increase in APX and CAT activity indicates the importance of these enzymes in the detoxification of $\mathrm{H}_{2} \mathrm{O}_{2}$ and protection against oxidative damages (Cia et al., 2012). Morais (2013), studying the combined action of abiotic stress factors, reported that the enzymatic behavior of the variety RB867515 was efficient in the regulation and detoxification of the ROS produced in the plant cell, indicating a greater tolerance of this variety to the different types of stress.

Figures 2 and $3 \mathrm{~B}$ and Table 1 present the results of the enzymes CAT and APX, respectively, comparing the varieties and the applied saline levels. In general, there was an increase in APX and CAT activity in all varieties when subjected to $100 \mathrm{mM} \mathrm{NaCl}$. Deuner et al. (2011) observed that seeds of cowpea genotypes maintain high germination and APX and CAT activity until the $\mathrm{NaCl}$ concentration of $100 \mathrm{mM}$. The variety RB867515 showed higher action of these enzymes in the repair of damages caused by salinity, due to the significant increase in APX and CAT activity, in comparison to the results for RB92579 and RB962962. Based on the results found for the control and the $\mathrm{NaCl}$ concentration of $50 \mathrm{mM}$, the lower the stress, the lower the activity of these enzymes, as reported by Azevedo (2013).

Many authors have observed that the increment in salinity causes increase in the activity of the enzymes CAT and APX, leading to reduction in the deleterious effects of $\mathrm{H}_{2} \mathrm{O}_{2}$ (Maia et al., 2010; Abogadallah et al., 2010). However, Carvalho et al. (2011), studying the acclimation of rice plants to salt stress, observed reduction of CAT when plants were exposed to $\mathrm{NaCl}$. According to Azevedo et al. (2011), the capacity of activation of the antioxidant system is one of the main mechanisms that allow the plant to tolerate the oxidative stress. Silva (2010), analyzing six sugarcane genotypes subjected to severe water stress, observed a response of up to $30.23 \%$ in APX activity. Quintela et al. (2015), evaluating water stress intensity and duration on the pathosystem sugarcane $\mathrm{x}$ Meloidogyne incognita, observed an increase in APX activity without affecting CAT activity in the tested water treatments. In maize and soybean crops, the enzymes CAT and APX acted in a similar way under extreme situations, increasing as a result of the severity of the applied stress (Vasconcelos et al., 2009). Azevedo (2013) observed increase in CAT and APX activity in sugarcane for increasing levels of salinity.

\section{Conchusions}

1. In the initial growth stage, the sugarcane variety RB867515 showed higher activity of the enzymes catalase and ascorbate peroxidase, in comparison to RB962962 and RB92579, which is an indication of its higher tolerance to salinity.

2. At the saline concentration of $100 \mathrm{mM} \mathrm{NaCl}$, there was greater production of the enzymes catalase and ascorbate peroxidase for the variety RB867515.

3. The variety RB962962 showed higher value of soluble proteins compared with the other studied varieties.

\section{Literature Cited}

Abogadallah, G. M.; Serag, M. M.; Quick, P. W. Fine and coarse regulation of reactive oxygen species in the salt tolerant mutants of barnyard grass and their wild-type parents under salt stress. Physiologia Plantarum, v.138, p.60-73, 2010. http://dx.doi. org/10.1111/j.1399-3054.2009.01297.x

Agarwal, S.; Pandey, V. Antioxidant enzyme responses to $\mathrm{NaCl}$ stress in Cassia angustifolia. Biologia Plantarum, v.48, p.555-560, 2004. http://dx.doi.org/10.1023/B:BIOP.0000047152.07878.e7

Arias, M. I. B.; Delgado, E. O.; Carmenate, R. V. Cambios fisiológicos de la caña de azúcar ante el déficit hídrico. México: Universidad Autónoma Chapingo. 1.ed. 1996. 135p.

Azevedo, R. A.; Alas, R. M.; Smith, R. J.; Lea, P. J. Response of antioxidant enzymes to transfer from elevated carbon dioxide to air and ozone fumigation, in leaves and roots of wild type and catalase-deficient mutant of barley. Plant Physiology, v.104, p.280292, 1998. http://dx.doi.org/10.1034/j.1399-3054.1998.1040217.x 
Azevedo, R. A.; Carvalho, R. F.; Cia, M. C.; Gratão, P. L. Sugarcane under pressure: An overview of biochemical and physiological studies of abiotic stress. Tropical Plant Biology, v.4, p.42-51, 2011. http://dx.doi.org/10.1007/s12042-011-9067-4

Azevedo, V. M. Ação combinada de fatores abióticos de estresse em cana-de-açúcar: Variáveis fisiológicas e bioquímicas. Recife: Universidade Federal Rural de Pernambuco, 2013. 57p. Dissertação Mestrado

Barbosa, M. R.; Silva, M. M. de A.; Willadino, L.; Ulisses, C.; Camara, T. R. Geração e desintoxicação enzimática de espécies reativas de oxigênio em plantas. Revista Ciência Rural, v.44, p.453-460, 2014. http://dx.doi.org/10.1590/S0103-84782014000300011

Carvalho, F. E. L.; Lobo, A. K. M.; Bonifacio, A.; Martins, M. O.; Lima Neto, M. C.; Silveira, J. A. G. Aclimatação ao estresse salino em plantas de arroz induzida pelo pré-tratamento de $\mathrm{H}_{2} \mathrm{O}_{2}$. Revista Brasileira de Engenharia Agrícola e Ambiental, v.15, p.416-423, 2011. http://dx.doi.org/10.1590/S1415-43662011000400014

Castrillo, M.; Fernandez, D.; Calcagno, A. M.; Trujillo, I.; Guenni, L. Responses of ribulose-1,5-biphosphate carboxylase, protein content, and stomatal conductance to water deficit in maize, tomato, and bean. Photosynthetica, v.39, p.221-226, 2001. http:// dx.doi.org/10.1023/A:1013731210309

Cia, M. C.; Guimarães, A. C. R.; Medici, L. O.; Chabregas, S. M.; Azevedo, R. A. Antioxidant responses to water deficit by droughttolerant and-sensitive sugarcane varieties. Annals of Applied Biology, v.161, p.313-324, 2012. http://dx.doi.org/10.1111/j.17447348.2012.00575.x

CONAB - Companhia Nacional de Abastecimento. Safra brasileira da cana-de-açúcar, 2014/2015. Levantamento de agosto, 2014. <http://www.conab.gov.br>16 Dez. 2014.

Deuner, C.; Maia, M. de S.; Deuner, S.; Almeida, A. da S.; Meneghello, G. E. Viabilidade e atividade antioxidante de sementes de genótipos de feijão-miúdo submetidos ao estresse salino. Revista Brasileira de Sementes, v.33, p.711-720, 2011. http://dx.doi. org/10.1590/S0101-31222011000400013

Foyer, C. H.; Shigeoka, S. Understanding oxidative stress and antioxidant functions to enhance photosynthesis. Plant Physiology, v.155, p.93-100, 2011. http://dx.doi.org/10.1104/pp.110.166181

Gallardo, A. L. C. F.; Bond, A. Capturing the implications of land use change in Brazil through environmental assessment: Time for a strategic approach? Environmental Impact Assessement Review, v.31, p.261-270, 2010. http://dx.doi.org/10.1016/j. eiar.2010.06.002

Gill, S. S.; Tuteja, N. Reactive oxygen species and antioxidant machinery in abiotic stress tolerance in crop plants. Plant Physiology and Biochemistry, v.48, p.909-930, 2010. http://dx.doi. org/10.1016/j.plaphy.2010.08.016
IPA - Instituto Agronômico de Pernambuco. Recomendações de adubação para o estado de Pernambuco. 2.ed. Recife: IPA, 2008. $198 \mathrm{p}$.

Maia, J. M.; Macedo, C. E. C. de; Voigt, E. L.; Freitas, J. B. S.; Silveira, J. A. G. Antioxidative enzymatic protection in leaves of two contrasting cowpea cultivars under salinity. Biologia Plantarum, v.54, p.159-163, 2010. http://dx.doi.org/10.1007/s10535-010$0026-\mathrm{y}$

Marin, F.; Nassifi, D. S. P. Mudanças climáticas e a cana-de-açúcar no Brasil: Fisiologia, conjuntura e cenário futuro. Revista Brasileira de Engenharia Agrícola e Ambiental, v.17, p.232-239, 2013. http:// dx.doi.org/10.1590/S1415-43662013000200015

Miller, G.; Suzuki, H.; Ciftci-Yilmaz, S.; Mittler, R. Reactive oxygen species homeostasis and signaling during drought and salinity stresses. Plant, Cell and Environment, v.33, p.453-467, 2010. http://dx.doi.org/10.1111/j.1365-3040.2009.02041.x

Morais, M. B. de. Ação combinada de fatores abióticos de estresse em variedades de cana-de-açúcar: Variáveis fisiológicas e bioquímicas. Recife: UFRPE, 2013. 75p. Dissertação Mestrado

Parida, A. K.; Das, A. B. Salt tolerance and salinity effects on plants: A review. Ecotoxicology and Environmental Safety, v.60, p.324-349, 2005. http://dx.doi.org/10.1016/j.ecoenv.2004.06.010

Quintela, M. P.; Pedrosa, E. M. R.; Willadino, L.; Rolim, M. M.; Silva, E. F. de F. e; David, M. F. de L. Intensity and duration of water deficit on the pathosystem sugarcane x Meloidogyne incognita. Revista Brasileira de Engenharia Agrícola e Ambiental, v.19, p.581586, 2015. http://dx.doi.org/10.1590/1807-1929/agriambi. v19n6p581-586

Silva, P. B. Aspectos fisiológicos de seis genótipos de cana-de-açúcar submetidos a estresse hídrico. Rio Largo: UFAL, 2010. 98p. Dissertação Mestrado

Siripornadulsil, S.; Traina, S.; Verma, D. P. S.; Sayre, R. T. Molecular mechanisms of proline-mediated tolerance to toxic heavy metals in transgenic microalgae. Plant Cell, v.14, p.1-11, 2012.

Sundfeld, E.; Machado, C. Ações para o desenvolvimento de processos industriais para conversão de biomassa em biocombustíveis. Brasília: EMBRAPA. <http://www.embrapa.br/imprensa/ artigos/2011/>. 10 Mai. 2013.

Vasconcelos, A. C. F.; Zhang, X.; Ervin, E. H.; Kiehl, J. de C. Enzymatic antioxidant responses to biostimulants in maize and soybean subjected to drought. Scientia Agricola, v.66, p.395-402, 2009. http://dx.doi.org/10.1590/S0103-90162009000300015

Willadino, L.; Oliveira Filho, R. A. de; Silva Júnior, E. A. da; Gouveia Neto, A. G.; Camara, T. R. Estresse salino em duas variedades de cana-de-açúcar: Enzimas do sistema antioxidativo e fluorescência da clorofila. Revista Ciência Agronômica, v.42, p.417-422, 2011. http://dx.doi.org/10.1590/S1806-66902011000200022 